\title{
Scintigraphy in postoperative follow-up of osteosynthesis of the femur with a bridge plate associated with an intramedullary pin in rabbits
}

[Cintilografia no acompanhamento pós-operatório de osteossíntese do fêmur com placa em ponte associada ao pino intramedular em coelhos]

\author{
N.F. Borges ${ }^{1}$, R. Serakides ${ }^{2}$, R.G. Santos ${ }^{3}$, S.O.F. Diniz ${ }^{4}$, V.N. Cardoso ${ }^{4}$, N.S. Ucros ${ }^{2}$, \\ R.C.S. Torres ${ }^{2}$, S.V. Cardoso ${ }^{5}$, C.M.F. Rezende ${ }^{2 *}$
}

${ }^{1}$ Universidade Federal do Recôncavo da Bahia - Cruz Almas, BA.

${ }^{2}$ Escola de Veterinária - Universidade Federal de Minas Gerais - Belo Horizonte, MG

${ }^{3}$ Centro de Desenvolvimento da Tecnologia Nuclear e Comissão Nacional de Energia Nuclear - Belo Horizonte, MG

${ }^{4}$ Escola de Farmácia - Universidade Federal de Minas Gerais - Belo Horizonte, MG

${ }^{5}$ Universidade Federal de Uberlândia - Uberlândia, MG

\begin{abstract}
The objective of this work was to monitor the consolidation of the femur after osteosynthesis with a bridge plate associated with the intramedullary pin using scintigraphy. We used seven New Zealand breed male rabbits, at 4 months of age, with a mean weight of $3.5 \mathrm{~kg}$. We performed a three-phase bone scintigraphy with technetium-labeled methylene diphosphonate (99mTc-MDP) before and after surgery, and 20, 50 and 90 days postoperatively. The activity index (AI) was calculated by dividing the average number of uptake counts in the region of the osteotomy by the average number of counts in the corresponding region in the contralateral limb. Radiography was performed before surgery, after surgery, and 15, 30, 45, 60 and 90 days postoperatively. We found a direct relationship between the activity index and progress of bone scintigraphy in the evaluation sequence over the period of observation. Scintigraphy allows monitoring of bone metabolism and measurement of vascularization and/or bone or tissue perfusion. The images obtained in the blood pool and static phases are the most appropriate for assessing bone metabolism in the context of this study. The bridge plate associated with the intramedullary pin promotes osteosynthesis with sufficient stability to allow bone consolidation.
\end{abstract}

Keywords: scintigraphy, rabbits, bridge plate, biological osteosynthesis

\section{RESUMO}

A cintilografia foi empregada no acompanhamento da consolidação de osteotomia experimental do fêmur após osteossíntese com placa em ponte associada ao pino intramedular. Foram usados sete coelhos machos, raça Nova Zelândia, com massa corporal de 3,5kg e idade média de quatro meses. A cintilografia óssea trifásica com metilenodifosfonato marcado com tecnécio-99m $\left(M D P-{ }^{99 m} T c\right)$ foi obtida antes e após a cirurgia, e nos dias 20, 50 e 90 do pós-operatório.O índice de atividade (IA) foi calculado por meio do quociente da média do número de contagens na região da osteotomia pela média do número de contagens na região correspondente, no membro contralateral normal. Paralelamente ao estudo cintilográfico, foram realizadas radiografias antes dos procedimentos cirúrgicos e aos 15, 30, 45, 60 e 90 dias após, para acompanhamento do processo de cura óssea. Encontrou-se relação direta entre o índice de atividade e a evolução do processo de consolidação óssea na avaliação cintilográfica sequencial ao longo do período de observação. A cintilografia óssea trifásica permite acompanhar o metabolismo ósseo, avaliar e mensurar a vascularização e perfusão tecidual. As imagens obtidas na fase de pool sanguíneo e na fase óssea são as mais adequadas para avaliação do metabolismo ósseo. A placa em ponte associada com o pino intramedular promove osteossíntese com estabilidade suficiente para permitir a consolidação ossea.

Palavras-chave: cintilografia, coelhos, placa em ponte, osteossíntese biológica

Recebido em 24 de outubro de 2011

Aceito em 1 de fevereiro de 2013

*Autor para correspondência (corresponding author)

E-mail: cleuzaufmg@gmail.com 


\section{INTRODUCTION}

The treatment of fractures aims to achieve bone consolidation and the early return of limb function (Piermattei et al., 2006). It can be performed using different methods. The techniques of indirect and biological reduction have been demonstrated the promotion of bone consolidation, reducing complication rates (Ruedi et al., 1998). Pin blocks, bridge plates and no-contact plates are examples of methods used for biological fixation. Biological internal fixation does not impair bone consolidation, restores the early function of the limb and meets the principles of minimal tissue injury (Perren, 2002).

To avoid the complications of extensive devitalization of the fragments in comminuted fractures, Müller and Witzel (1984) and Heitemeyer and Hierholzer (1985) applied the biological osteosynthesis with bridge plates (BP) technique. This technique does not directly address the fracture site, but promotes its stabilization and maintains the anatomic axis and length of the bone through distal and proximal fixation (Osório et al., 1994; Falavinha, 1996). This method induces the formation of radiographically identifiable bone callus, extensions of which can sometimes hinder the assessment for implant removal (Mattos et al., 1997).

Monitoring fracture consolidation is a necessary practice of clinical interest because it determines the physical characteristics of the bone segment under repair. Postoperative monitoring is routinely performed with radiographs, which show the structural aspect of the bone. However, other methods such as bone scintigraphy can be used to assess functional bone, which can reveal more detailed information. It allows the identification of increased bone metabolism, which usually precedes structural changes. Bone scintigraphy is therefore useful as an early assessment method that complements radiography (Lamb, 1991).

Bauer and Wendeberg (1959) conducted the first scintigraphy for the follow-up of fractures in 1959 , using strontium 85 (85Sr), and reported that high uptake of the isotope indicated the lack of consolidation. The uptake of an isotope is measured by the activity index (AI), which is calculated as the ratio of the average number of counts from the region of interest (ROI) to the average number of counts received in the corresponding region in the contralateral limb. This index is directly related to osteogenesis, which is progressively greater in bone consolidation, in delayed consolidation and hypertrophic pseudarthrosis, respectively (Barros and Barbieri, 1994).

Despite all of the advances in orthopedic surgery, fracture consolidation still faces some challenges in both human and veterinary medicine. Techniques have evolved, but the clinician is occasionally faced with complicated fractures. Thus, it is necessary to develop new materials, techniques and less invasive approaches, as well as more effective methods for monitoring bone healing. In this context, the main objective of this study is to use three-phase bone scintigraphy to monitor bone consolidation after treatment with a bridge plate associated with the intramedullary pin in the fixation of osteotomies of rabbit femurs.

\section{MATERIALS AND METHODS}

This study was approved by the Ethics Committee on Animal Experimentation of the Federal University of Minas Gerais (CETEA protocol 034/05).

We used seven four-month-old New Zealand male rabbits (Oryctolagus cuniculus) with an average body weight of $3.5 \mathrm{~kg}$. The animals were subjected to experimental osteotomy of the third median of the right femur and fixation with a bridge plate associated with the intramedullary pin.

The protocol for anesthesia of the rabbits was sedation with xylazine $\mathrm{HCl}(2.5 \mathrm{mg} / \mathrm{kg})$ intramuscularly, followed by induction with propofol $(10 \mathrm{mg} / \mathrm{kg})$ and epidural anesthesia with bupivacaine $(12,5 \mathrm{mg} / \mathrm{Kg})$. Before surgery, tramadol hydrochloride $(1 \mathrm{mg} / \mathrm{kg})$ was administered intramuscularly for pain control and cephalexin $(30 \mathrm{mg} / \mathrm{kg})$ was administered for antibiotic prophylaxis. For the femoral osteotomy, a cranio-lateral cutaneous incision of approximately $2 \mathrm{~cm}$ was made in the third median of the right thigh. A fascia lata incision followed, with cranial removal of the caudal and lateral vastus muscle of the femoral 
biceps. Exposure of the femur and cross-section of the bone were performed with an oscillatory saw coupled to an electric pneumatic orthopedic drill, under constant irrigation with Ringer lactate solution. An intramedullary pin, $2 \mathrm{~mm}$ in diameter was introduced for the bone alignment. Two other skin incisions of about $2 \mathrm{~cm}$ were made in the proximal and distal third of the femur. A 2.0 plate was introduced by sliding it over the femur in the proximal direction towards the greater trochanter, followed by the alternating fixation of two bicortical screws, $2 \mathrm{~mm}$ in diameter, at each end. The bridge plate was fixed at the ends of the femur using four screws.

Clinical monitoring was performed from the time of osteotomy up to 90 days postoperatively. The presence of inflammation, pain sensitivity and wound dehiscence was monitored. Antibiotics and anti-inflammatory drugs were not used after surgical procedures.

Scores were established for radiographic evaluation according to criteria described by Yuehue and Friedman (1999). Craniocaudal (CC) and mediolateral (ML) projections of the limb were performed before surgery, immediately after surgery, and 15, 30, 45, 60 and 90 days postoperatively, in order to compare the projections and assess bone repair. The projections were compared by evaluating the appearance at the osteotomy line (missing $=3$, poorly defined $=2$, reduced $=1$ and complete $=$ 0 ), the formation and size of the bone callus (absent $=0$, discrete $=1$, moderate $=2$; exuberant $=3$ ), the periosteal reaction (absent $=$ 0 , discrete $=1$, moderate $=2$ and exuberant $=3$ ) and remodeling (absent $=0$, discrete $=1$, moderate initial $=2$, moderate advanced $=3$ and total $=4$ ).

For the three-phase bone scintigraphy, the radiopharmaceutical methylene diphosphonate, labeled with technetium-99m ( ${ }^{99 \mathrm{~m}}$ Tc-MDP), was used. The animals were anesthetized with a combination of ketamine $(30 \mathrm{mg} / \mathrm{kg})$ and xylazine $\mathrm{HCl}(2.5 \mathrm{mg} / \mathrm{kg})$ intramuscularly, and positioned supine under a gamma camera equipped with a low energy collimator (Nuclide $^{\mathrm{TM}}$ TH 22, Mediso, Hungary).

We performed the first flow images 3 seconds after the intravenous administration of $1.6 \mathrm{mCi} / \mathrm{kg}$ of 99mTc-MDP. Thirty images (one image every 3 seconds) were acquired in this first phase. After five minutes, the second phase of scintigraphy or blood pool was performed, with an acquisition time of 300 seconds and three hours (3h) after injection of the radiopharmaceutical. Static image acquisition was performed with the radiotracer already incorporated into the bone with an acquisition time of 600 seconds. These images were taken before the surgery and 20, 50 and 90 days postoperatively. Quantitative assessments were made by calculating the activity index (AI) for each scintigraphic phase. The vascular phase was analyzed by measuring the capture in the last image produced, which corresponds to the moment at which the radiopharmaceutical reaches the vascular bone bed. Areas involving the epiphyses and the entire femoral diaphysis of both femurs (right and left) were delineated and the activity of these regions, called ROIs (regions of interest), was measured. The same methodology was used to measure the capture of ROI in the blood pool and static phases. In each limb, the operated (target) and contra-lateral (non-target) limbs, the capture of the ROI was measured. For each phase, we calculated the ratio between target and non-target capture to obtain the activity index (AI).

The images were analyzed quantitatively, and radioactivity was determined in the demarcation areas of the ROIs involving the epiphysis and the entire femoral diaphysis of both femurs (right and left). The areas corresponding to the ROIs were copied and transported to the corresponding contralateral region (not target). The quotient between the average count on the normal and the osteotomized femur was the individual activity index (AI).

The scintigraphic and radiographic data were subjected to variance analysis (ANOVA) with a $5 \%$ significance level.

\section{RESULTS}

The animals showed normal clinical evolution and no signs of infection or complications were observed. The surgical wound healing occurred by first intention, with the stitches removed on the eighth day. Support of the operated limb with discrete claudication and the presence of pain on palpation were observed until the second week. 
Complete absence of pain was observed in the third week.

At 15 days postoperatively, radiographic examination showed mild to moderate periosteal reaction (Fig. 1A) in most animals $(71.42 \%)$ and exuberant periosteal reaction in two animals $(28.58 \%)$. During this period, the presence of a discrete $(85.72 \%)$ to moderate $(14.28 \%)$ bone callus was observed, with the osteotomy line evident in $85.72 \%$ of the animals and poorly defined in $14.28 \%$.

At 30 days postoperatively, there was an increase in bone callus (Fig. 1B) and periosteal reaction in varying degrees in all animals, and reduced $(85.72 \%)$ or poorly defined $(14.28 \%)$ osteotomy line.

At 45 days postoperatively, there was periosteal reaction in $71.42 \%$ of the rabbits, the callus was mild to moderate in most animals $(85.72 \%)$, exuberant in one $(14.28 \%$ ), with moderate initial remodeling of the callus in $85.72 \%$ and moderately advanced in $14.28 \%$ of the animals. The osteotomy line was reduced $(28.57 \%)$ to poorly defined (71.42\%) (Fig. 1C).

At 60 days, radiography showed a reduced $(14.28 \%)$, poorly defined $(57.14 \%)$ and absent (28.57\%) osteotomy line (Fig. 2). There was moderately advanced $(71.42 \%)$ and moderate initial $(28.57 \%)$ bone remodeling with slight $(57.14 \%)$ to moderate $(42.85 \%)$ callus.
At 90 days, advanced remodeling was present, with callus reduction, complete absence of the osteotomy line (Fig. 3) in 57.14\% of the animals and poorly defined in others.

Scintigraphic evaluation of blood pool (Fig. 4) and static images (Fig. 5) showed that there was a diffused increase in the capture of the radiopharmaceutical along the femur during the first 20 days (Fig. 4B and 5B). It also revealed decreased capture as the bone remodeling process occurred, as was observed radiographically between 45 and 60 days.

At 90 days, there was similarity between the capture of the two limbs. Comparing the observation periods for each phase of scintigraphy, we found that the activity index rose at 20 days compared to the preoperative period, decreased at 50, and returned to initial parameters at 90 days.

In one animal, an increasing activity index was observed between 50 and 90 days. That is, the capture of the radiopharmaceutical in the operated limb increased from $72 \%$ to $92 \%$, with an osteotomy line radiographically observed in this animal (Fig. 6), in contrast to other animals. Scintigraphy showed increased osteoblastic activity in this animal, indicating delayed bone consolidation, as verified by the increased capture of the radiopharmaceutical at 50 days and continued hypercapture at 90 days in the osteotomy line (Fig. 7).

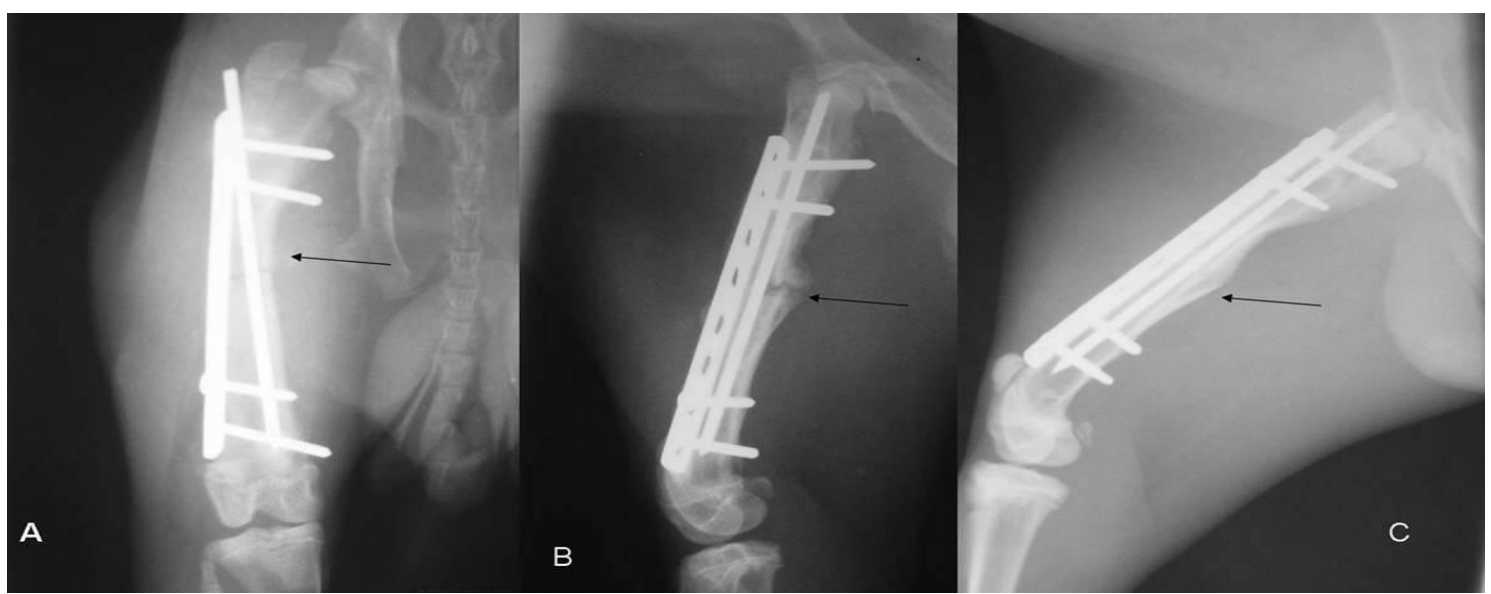

Figure 1. Radiographic images of the femur of rabbits subjected to osteotomy and fixation with bridge plates associated with the intramedullary pin. A) Cranio-caudal, incidence, 15 days postoperatively (POP): presence of periosteal reaction (arrow), B) Medio-lateral incidence 30 days POP: moderate bone callus, presence of osteotomy line (arrow) C) 45 days, reduced osteotomy line (arrow). 


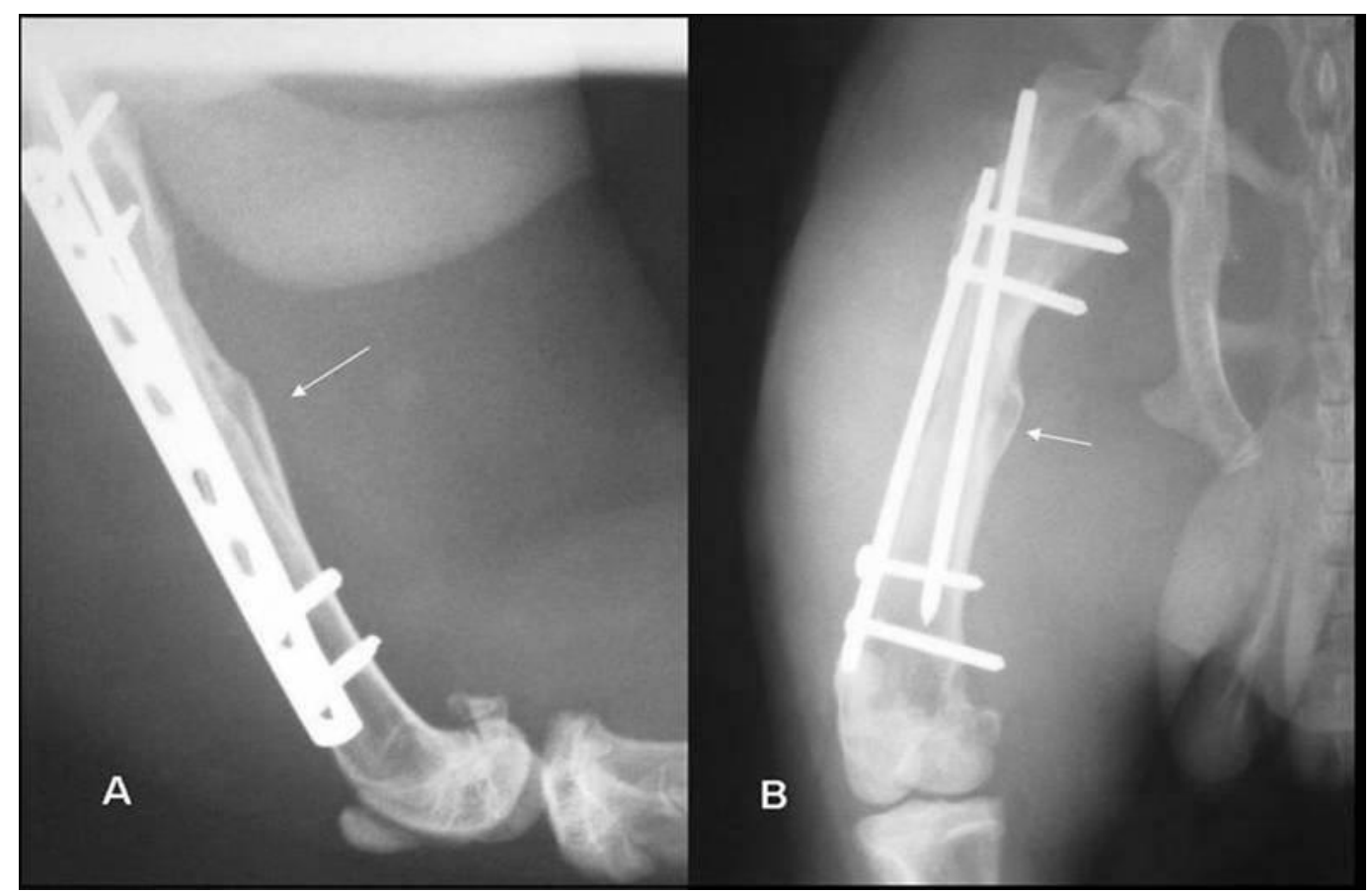

Figure 2. Radiographic images of the femur of rabbits subjected to osteotomy and fixation with bridge plate associated with the intramedullary pin at 60 days. A) medio-lateral incidence, bone callus, absent osteotomy line and complete bone bridge, moderate bone remodeling (arrow) B) cranio-caudal incidence, bone callus, osteotomy line absent, moderate bone remodeling (arrow).

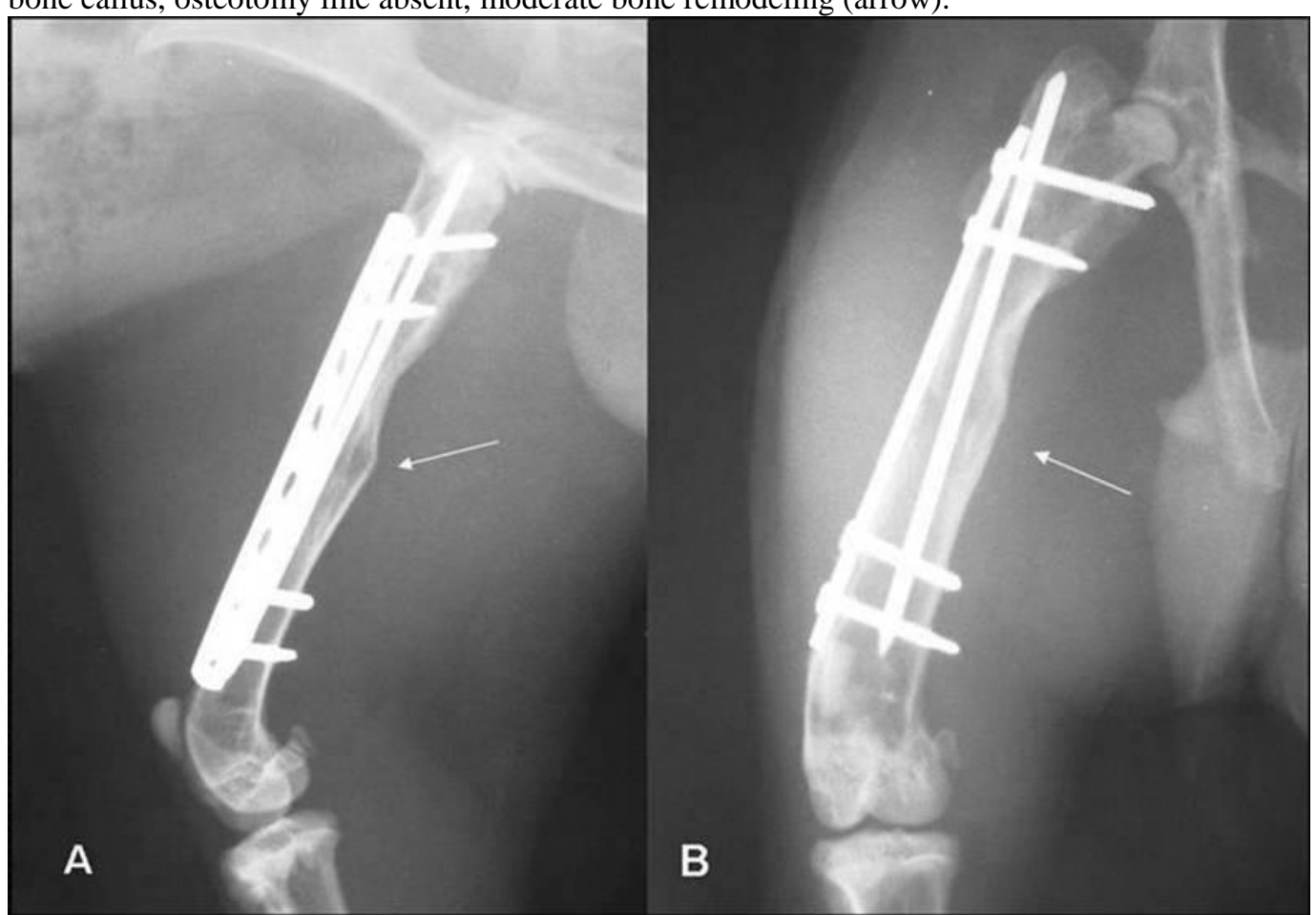

Figure 3. Radiographic images of the femur of rabbits subjected to osteotomy and fixation with a bridge plate at 90 days. A) medio-lateral incidence, reduced bone callus, absence of line, advanced remodeling (arrow) B) cranio-caudal incidence, bone callus absent, no fracture line, cortical continuity and advanced bone remodeling (arrow). 


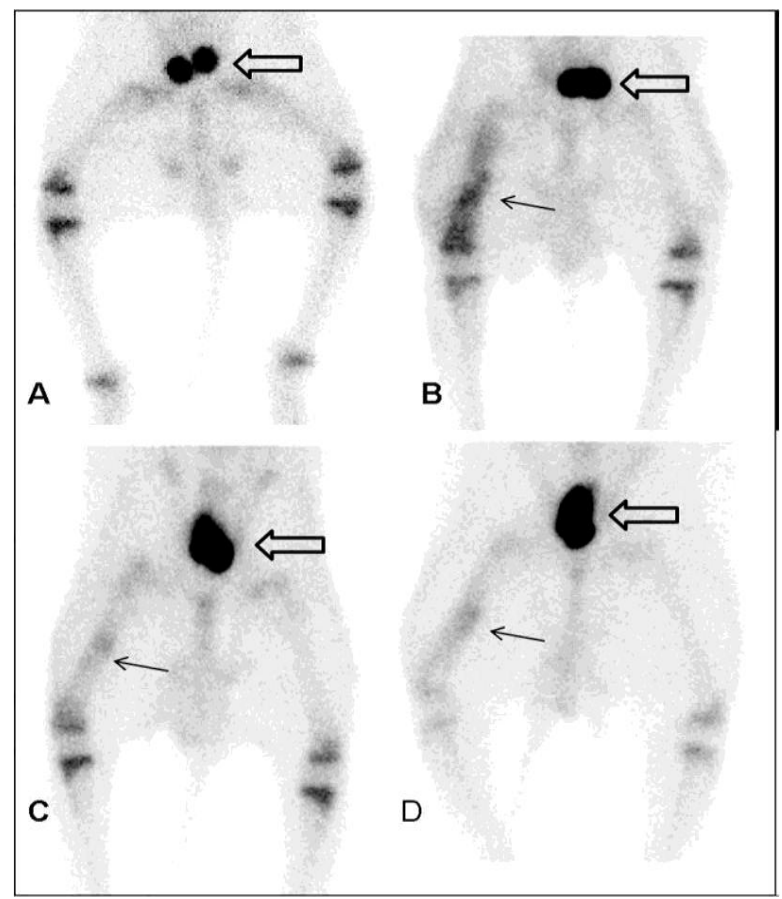

Figure 4. Scintigraphic images of hind limbs of rabbits subjected to osteotomy of the right femur and fixation with bridge plate associated with the intramedullary pin - right femur blood 'pool' phase (operated) and left femur (non-op) A) Preoperative - similar images of two femurs. B) Scintigraphic image at 20 days - increased capture of the ${ }^{99 \mathrm{~m}}$ Tc-MDP radiotracer in the right femur. C) Scintigraphic image at 50 days, comparatively lower capture in the operated femur relative to the previous period. D) Scintigraphic imaging at 90 days. Bladder (empty arrow) and osteotomy region (black arrow).

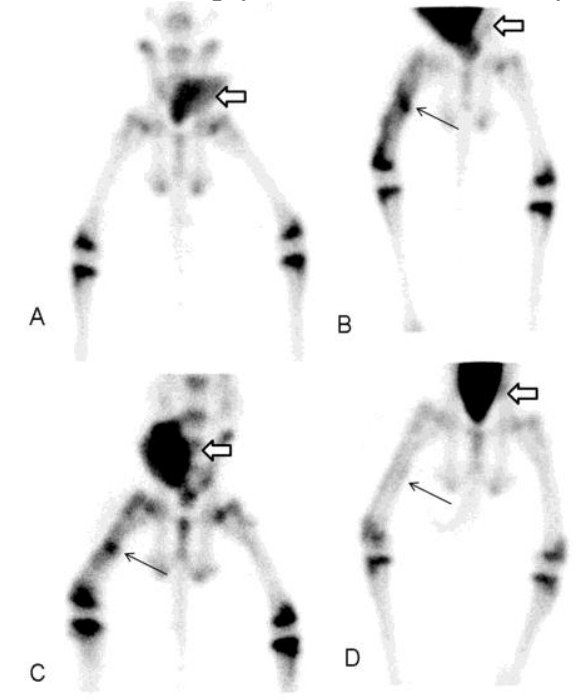

Figure 5. Scintigraphic images of hind limbs of rabbits subjected to osteotomy of the right femur and fixation with bridge plate associated with the intramedullary pin - static phase - right femur (operated) and left femur (non-operated) A) Preoperative period - similar images of the two femurs. B) Scintigraphic imaging at 20 days - Increased capture of the radiopharmaceutical ${ }^{99 \mathrm{~m}}$ Tc-MDP in the right femur. C) Scintigraphic imaging at 50 days, comparatively lower capture in the operated femur relative to the previous period. D) Scintigraphic imaging at 90 days - note the similarity between the right femur (operated) and left. bladder (empty arrow) and osteotomy region (black arrow). 


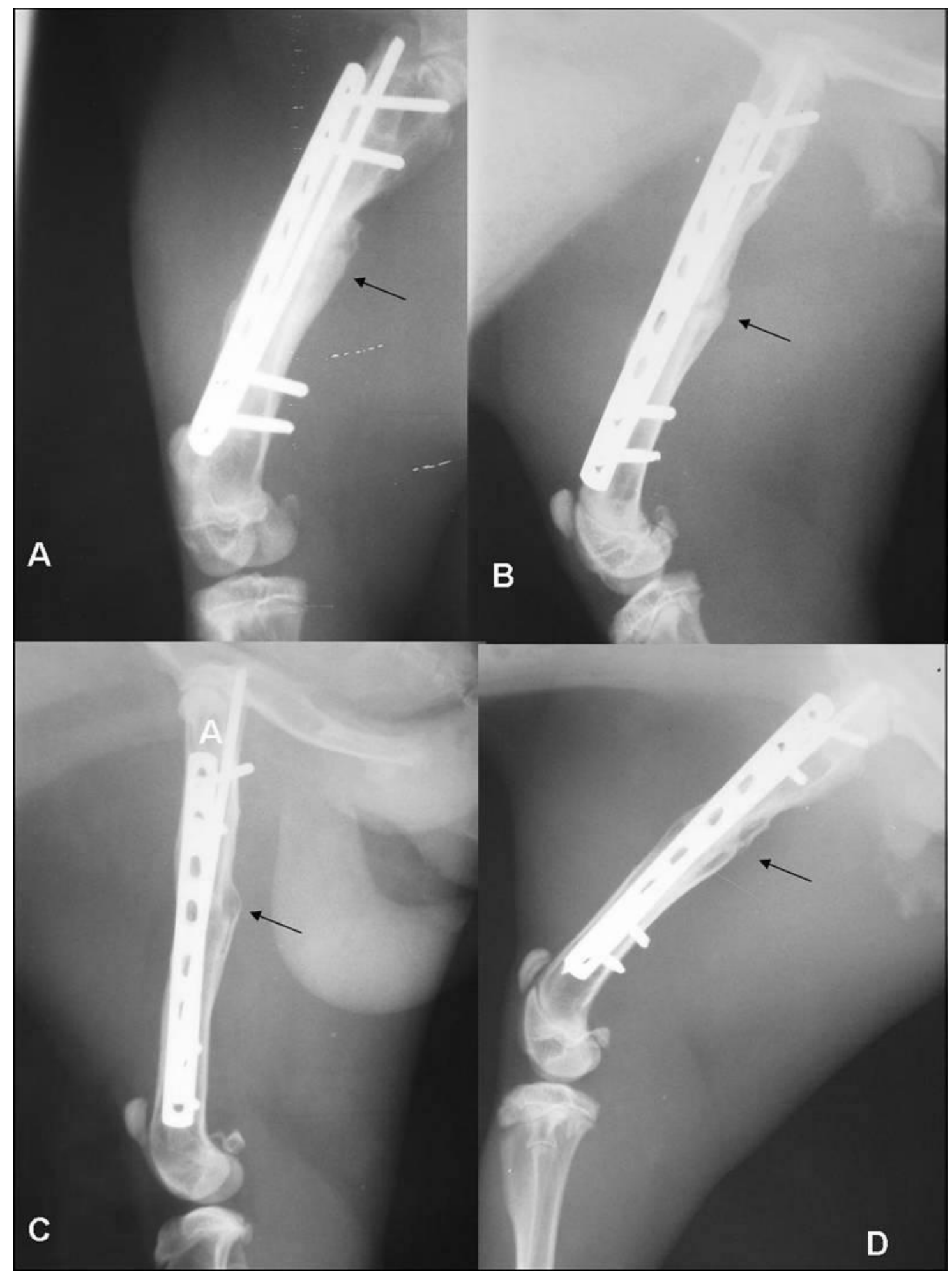

Figure 6. Radiographic images of the femur of a rabbit subjected to osteotomy and fixation with bridge plate associated with the intramedullary pin. A) at 30 days intense periosteal reaction and exuberant bone callus (black arrow) B) at 45 days and C) at 60 days - osteotomy line and bone callus present D) presence of moderate bone callus, fracture line present. 


\section{Borges et al.}

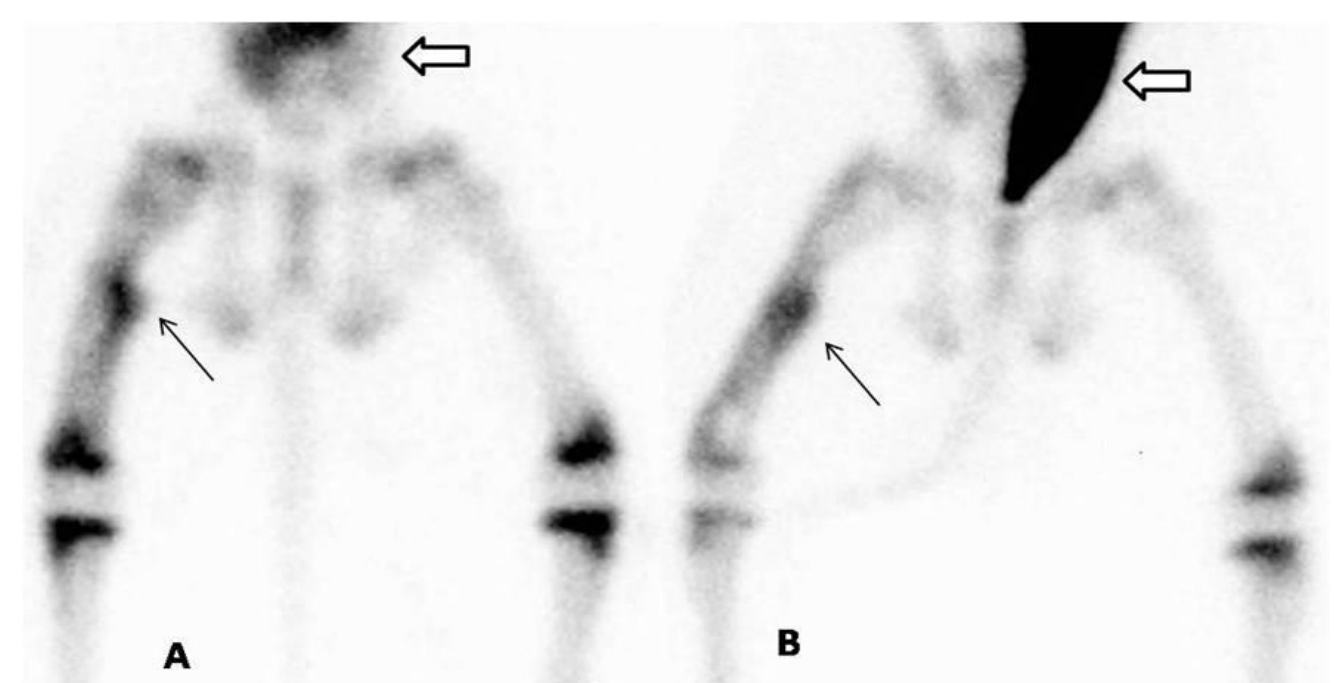

Figure 7. Scintigraphic images of the femur of a rabbit subjected to osteotomy and fixation with bridge plate associated with the intramedullary pin. Static phase, showing hypercapture in the osteotomy focus (delayed union). A) 50 days, intense capture of the ${ }^{99 \mathrm{~m}} \mathrm{Tc}-\mathrm{MDP}$ radiotracer in the right femur. B) 90 days, permanent capture of the radiotracer in the osteotomized region, Bladder (empty arrow) and osteotomy region (black arrow).

\section{DISCUSSION}

The minimally invasive approach of placing a bridge plate associated with the intramedullary pin is intended to preserve soft tissue and fix the plate only on the bone extremities as described by Shimabukuro et al. (1997) and Vasconcelos et al. (2004). This flexible fixation does not interfere with the return of limb function and offers the advantage of reducing the manipulation of tissues.

Radiographic evaluation was an important tool used to monitor the evolution of bone consolidation and facilitated the understanding of scintigraphic images. Due to the difficulties in obtaining the technetium, scintigraphy was performed at intervals that differed from the radiograms. With this limitation, scintigraphic evaluation was performed at interim periods to radiographic evaluations except at 90 days. Despite the reduced number of tests, it was possible to monitor bone metabolism during the consolidation period.

Conventional radiography is necessary to monitor the evolution of a fracture, with information on the type, alignment of the fragments and the state of calcification of the callus (Ricciardi, 1991) but does not provide information on bone metabolism that can be evaluated by scintigraphy.

The use of bone scintigraphy provides additional early information that allows monitoring of the evolution of bone consolidation in its initial phase. Radiography and scintigraphy are complementary in the evaluation of skeletal changes, with radiographs showing anatomical changes usually resulting from changes in bone mineral content and bone scintigraphy indicating the metabolic state produced by changes in bone vascularity and osteoblastic activity. Scintigraphy shows bone changes before radiological changes (Lamb, 1991; Murray, 1998). The combination of radiography and scintigraphy thus improves the understanding of the process of bone healing.

Scintigraphy proved to be a valuable instrument in the assessment of the process of bone healing, as verified by Lamb (1991). Given its characteristics, it is an appropriate test for assessing the evolution of a fracture, with the possibility of altering the prognosis of the consolidation process, based on the appearance of the image obtained and quantification of the activity index.

The delay in consolidation is translated by the continued concentration of the 
radiopharmaceutical at the site. This is evidenced in this study in one animal whose activity index increased between 50 and 90 days, which was confirmed radiographically by the presence of the fracture line at 90 days (Fig. 6), a finding consistent with literature (Barros and Barbieri, 1994; Murray 1998; Etchebehere et al., 2000).

Thus, as reported by Dyke and Aaron (2010), in this study it was possible to noninvasively assess vascularization and/or bone or tissue perfusion. The qualitative analysis revealed images of the flow and blood pool phases (Fig. 4), and quantitative analysis showed vascular tissue perfusion. The statistically significant differences observed between different periods only for the blood pool and static phases suggest that these are more important than the flow phase for the evaluation of bone metabolism in the context of the study.

The static phase proves to be the best stage for qualitative and quantitative analysis of bone consolidation, since the radiotracer is incorporated into the bone tissue and the image is clearer. Quantitative findings in this study are compatible with the qualitative assessment that shows localized and intense capture of the radiotracer in the focus of the osteotomy at 20 (Fig. 5B) and 50 days (Fig. 5C). These values returned to preoperative values at 90 days, as the operated and non-operated bone become similar in appearance (Fig. 5D). This indicates less osteoblastic activity, probably due to advanced remodeling at the osteotomy focus as reported by Barros and Barbieri (1994) and Etchebehere et al. (2000), with return of the bone to its original form.

\section{CONCLUSIONS}

The bridge plate associated with the intramedullary pin promotes osteosynthesis with sufficient stability to allow for consolidation at an average of 60 days. The three-phase bone scintigraphy allows monitoring of bone metabolism and qualitative and quantitative assessment of the vascularization and/or bone or tissue perfusion with monitoring of the consolidation process and identification of failures in the evolution of this process. The images obtained in the blood pool and static phases are the most suitable for assessing bone metabolism in the context of our study.

\section{ACKNOWLEDGMENT}

The authors would like to thank CNEN Comissão Nacional de Energia Nuclear and FAPEMIG for their financial support.

\section{REFERENCES}

BARROS, J.W.; BARBIERI, C.H. Abnormalities of bone consolidation Part II - scintigraphic index of its evolution. Rev. Bras. Ortop., v.29, p.159-162, 1994.

BAUER, G.C.H.; WENDEBERG, B.; SWEDEN, M. External counting of $\mathrm{Ca}^{47}$ and $\mathrm{Sr}^{85}$ in studies of localized skeletal lesions in man. J. Bone Joint Surg. B.r., v.41B, p.558-580, 1959.

DYKE, J.P.; AARON, R.K. Noninvasive methods of measuring bone blood perfusion. Ann. N. Y. Acad. Sci., v.192, p.95-102, 2010.

ETCHEBEHERE, E.C.S.; PEREIRA NETO, C.A.C.; ZUPPI, G.N. et al. Triphasic bone scintigraphic to guide the removal of metallic implants in fractures: a preliminary study. Rev. Bras.Ortop., v.35, p.67-72, 2000.

FALAVINHA, R.S. Biological fixation of multifragmented fractures of the femur. Rev. Bras. Ortop., v.31, p.449-456, 1996.

HEITEMEYER, U.; HIERHOLZER, G. Die überbrückend osteosynthese bei geschlossenen stuckfrakturen des femurschaftes. Aktuel. Traumatol., v.15, p.205-209, 1985.

LAMB, C.R. The principles and practice of bone scintigraphy in small animals. Semin. Vet .Med. Surg.,v.6, p.140-153, 1991.

MATTOS, C.A.; ZUPPI, G.N.; KÖBERLE, G. Treatment of femur fractures by biological fixation method: bridge plating and locked intramedullary nail. Rev. Bras. Ortop., v.32, p.425-430, 1997.

MULLER, K. H.; WITZEL, U. Die brückenplatte zur osteosynthese bei ossären shaftdefekten des femur nach fehlschlägen von plattenosteosynthesen. Unfallheilkunde v.87, p.1-10, 1984.

MURRAY, I.P.C. Nuclear medicine in clinical diagnosis and treatment. 2.ed. Edinburgh, Scotland: Churchill Livingstone, 1998. 2074p.

OSÓRIO, L.; OSÓRIO, E.G.; AMARAL, F.G. Treatment of comminuted fractures of the femur by the method of bridge plating. Rev. Bras. Ortop., v.29, p.855-860, 1994.

PERREN, S.M. Evolution of the internal fixation of long bone fractures. J. Bone Joint Surg. Br., v.84-B, p.1093-1110, 2002. 
PIERMATTEI, D.L.; FLO., G.; DECAMP, C.E Handbook of small animal orthopedics and fracture repair. 4.ed. St. Louis: Saunders, 2006. 832p.

RICCIARDI, L. Il trattamento delle fratture con il fissatore esterno di Hoffmann. Biologia, diagnostica strumentale, risultati. Padova: Piccin- Nuova Libraria, 1991. 386p.

RUEDI, T.P.; SOMMER, C.; LEUTENEGGER, A New techniques in indirect reduction of long bone fractures. Clin. Orthop. Relat. R., v.347, p.27-34, 1998.
SHIMABUKURO, E.H.; TUCCI NETO, P.F.; CHOHFI, M. et al. Comparative study of the bridge plating and locked intramedullary nail in comminuted diaphyseal fractures of the femur. Rev. Bras. Ortop., v.32, p.221-228, 1997.

VASCONCELOS, J.W.; MORAIS, S.V.; PORTO, L.C.K. et al. Treatment of comminuted fractures of the femur using the bridge plating. Rev. Bras. Ortop., v.39, p.415-422, 2004.

YUEHUEI H.; FRIEDMAN, R. J.: Animal models in orthopaedic research, CRC Press, p.208, 1999. 217p. 